\title{
Development of Ethnic Identity among American College Students of Asian Indian Descent
}

\author{
Naveen Mehrotra', Nayan Mehrotra', Anna Petrova ${ }^{3}$ \\ ${ }^{1}$ Board Certified in Pediatrics, Founder \& Executive Director, Shri Krishna Nidhi Foundation. \\ ${ }^{2}$ BS Psychology, Seton Hall University. \\ ${ }^{3}$ Professor, Pediatrics, Rutgers- Robert Wood Johnson Medical School. \\ DOI: https://doi.org/10.24321/2349.2880.202002
}

I $\quad \mathbf{N} \quad \mathbf{F} \quad \mathbf{O}$

\section{Corresponding Author:}

Naveen Mehrotra, Board Certified in Pediatrics, Founder \& Executive Director, Shri Krishna Nidhi Foundation.

E-mail Id:

thesknfoundation@gmail.com

\section{Orcid Id:}

https://orcid.org/0000-0003-4646-5850

How to cite this article:

Mehrotra N, Mehrotra N, Petrova A. Development of Ethnic Identity among American College Students of Asian Indian Descent. Ind J Youth Adol Health 2020; 7(1): 7-14

Date of Submission: 2020-06-18

Date of Acceptance: 2020-07-24

\section{$\begin{array}{llllllll}\mathbf{A} & \mathbf{B} & \mathbf{S} & \mathbf{T} & \mathbf{R} & \mathbf{A} & \mathbf{C} & \mathbf{T}\end{array}$}

Objectives: Ethnic identity is a cultural self-concept associated with formation of social identity and psychological well-being as well as academic performance of diverse population of college- age students. This study was designed to identify factors associated with ethnic identify formation among American college students of the Asian Indian descent.

Methods: College students who participated in the Association of Indians and South Asian social networks were surveyed. In addition to demographic, family and culture-related behavior questions, Multigroup Ethnic Identity Measure (MEIM) instrument was used to identify parameters that characterized the development of ethnic identity: total score, search, and affirmation, belonging, and commitment (ABC). Regression model was used to identify factors associated with formation of ethnic identity of the studied youth.

Result: Almost all respondents were born in the U.S. from the monoethnical Asian Indian families. The total ethnic identify scores were higher if the participants reported using native language at home, attendance at a religious/cultural Sunday school and dance and/or ethnic music classes, visitation of the parent's country of origin in addition to the father's religious and parental membership/leadership in the ethnic/ religious organizations. Participation in dance and or/ethnic music classes and use of native language at home was strongly associated with formation of ethnic identity.

Conclusion: Participation in cultural and ethnic events as well as paternal religion and use of native language are major factors that impact exploration and commitment stages of ethnic identity formation that should be addressed in professional psychological counseling of American youth of Asian Indian descent.x

Keywords: Ethnic Identify, College Students, Youth, Adolescence, Asian Indians 
Racial and ethnic minority youth in addition to the agerelated straggle of self-identity formation are also at the main stage for searching and developing their cultural self-concept..$^{1-3}$ Cultural self-concept is related to formation of ethnic identity, ${ }^{4}$ which is a unique developmental task that could influence different aspects of formation of social identity and psychological well-being. ${ }^{5-7}$ There is direct relationship of ethnic identity with the youth ability of coping and development of self-esteem. ${ }^{8}$ Importantly, formation of ethnic identity is one of the factors that decrease mental health symptoms, including depression, anxiety, and externalizing behavior for youth from all cultural groups..$^{9,10}$

Ethnic identity formation is a dynamic and multidimensional concept. ${ }^{11,12}$ Construct of ethnic identity is consequential for the psychosocial, academic, and well-being of culturally diverse young populations ${ }^{13-16}$ who demonstrate a stronger relationship between ethnic identity and personal well-being than adults, ${ }^{17}$ Several studies have discussed the variability in development of ethnic identity among different cultural groups of adolescents and young adults. ${ }^{9-11}$ However, data on development of ethnic identity of South Asian youth remains limited. In general, Asian Indian youth express commitment and loyalty toward family cultural traditions $1^{8,19}$ even though parental restriction of autonomy could interrupt development of their ethnic identity. ${ }^{20,21}$ Ethnic identity formation of Asian Indian youth has been recognized as a challenging issue that is in addition to the parental stress requiring professional physiological counseling. ${ }^{22}$ In the present study, we evaluated the role of demographic and family characteristics in formation of stages of ethnic identity, including belonging and attitude toward group, ethnic behaviors and meaning of self-ethnicity in American youth of Asian Indian origin.

\section{Methods}

\section{Recruitment of Participants}

We designed a cross-sectional survey study that targeted college age youth of Asian Indian origin. The paper questionnaire was distributed to 200 Rutgers University students at the time of cultural events organized by the Association of Indians. Additionally, the link through Kwiksurveys.com was created and used to distribute the questionnaire to the Asian Indian social networks, including Facebook of the Shri Krishna Nidhi (SKN) Foundation. No collection of private identifiers was preserved to safeguard the anonymous status of participants in our study. The responses to the distributed survey were collected from June 2011 to December 2011. The Institutional Review Board (IRB) at the Saint Peters University Hospital approved this study. No informed consent signed by the participants had been required due to the anonymous nature of this survey study.

\section{Measurement of Ethnic Identity}

We used the modified 12 items tool that excluded the measure of "other-group orientation" from the 14-item Multigroup Ethnic Identity Measure (MEIM) ${ }^{23,24}$ scale that has been validated for assessment of ethnic identity of adolescents from different cultural backgrounds. No written permission from Dr. Phinney was required but notification of study results and publications. The MEIM items are scored on a 4-point Likert scale (1=strongly disagree, 2=disagree, 3=agree, and 4=strongly agree). Higher scores on the MEIM indicate a stronger individual perception of ethnic identity. Means of Total Ethnic Identify (TEI) score and scores of two components separately, including Ethnic Identity Search (EIS) and Affirmation, Belonging, and Commitment $(A B C)$ were calculated. ${ }^{24,8}$ EIS and $A B C$ are two stages of development of ethnic identity characterized by exploration and commitment, respectively that can occur at any time during a child' development. ${ }^{23}$ The MEIM is a valid and reliable tool that is widely used for assessment of ethnic identity formation across ethnic groups of every age. ${ }^{24,8}$ The reliability of $A B C$ estimated in a large study on adolescents from diverse backgrounds was found to be higher $(a=0.90)$ than those for EIS $(a=0.77) .{ }^{25}$ Revised MEIM was found to have good internal consistency. ${ }^{26}$ In addition, participants were asked to answer the demographic and family-related questions: parental and self-perception of ethnicity, place of birth, type of high school attended, area of upbringing, language spoken at home, parental marital status and religious orientation, and their membership/ leadership in ethnic/religious organization, subscription to ethnic television at home, attendance of religious/cultural Sunday school, dance and or/ethnic music classes, travel to parent's county of origin, and visit of grandparents/ relatives to the U.S. The items have been dichotomously recorded and coded as 1 and 0 if the answer was "Yes" or "No, "respectively. The returned questionnaire was included in the final analysis if $100 \%$ of MEIM and at least $80 \%$ questions on demographic and family characteristics were completed.

\section{Statistical Analysis}

We used Analysis of Variance (ANOVA) to compare means of the ethnic identity scores estimated with respect to the responses to the demographic and family characteristics of participants (Table II). Variables showing a difference in mean ethnic identity scores at a level of $P<0.05$ were entered into the General Linear Models (GLM) to identify a predictive effect of selected demographic and family characteristics on TEI and separately for the EIS and ABC subscales (Table III). We tested the multi-collinearity effect with Variance Inflation Factor (VIF) that assesses how much the variance of an estimated regression coefficient increases if identified predictors are correlated. The VIF 
indicates no correlation if it is equal 1, problems with multi-collinearity if VIF is between 5 and 10 . If the VIF goes above 10 , the regression coefficients poorly estimate the associations of predictors with dependent variable due to multi-collinearity. ${ }^{27}$ The proportional distribution of responses to the 4-point Likert scale was used to assess the contribution of each item of MEIM to the TEI score and separately to the EIS and ABC subscales. Data are reported as percentages (\%), means, regression coefficient $(\beta)$, and 95\% Confidence Interval $(95 \% \mathrm{Cl})$. STATISTICA 13.2 was used for the data analysis. All statistical tests were 2-sided with the significance level set at $P$-value of less than 0.05 .

\section{Result}

One hundred two completed paper questionnaires among 200 surveyed and 83 completed questionnaire online of which 22 were excluded because 12 of them identified themselves other than South Asian and 10 did not complete all MEIM. Majority of the 163 studied participants were from the mono-ethnical Asian Indian families $(94.5 \%$ of fathers and $93.3 \%$ of mothers), suburban areas (89.4\%), had married parents (97.4\%) and religious mothers (97.5\%) and fathers $(80.0 \%)$, with a birth in the U.S. (73.5\%). Between 41 participants who were born outside of the US, $68.3 \%$ reported the U.S. residency for 10 or more years. As shown in Table I, more than half of the participants reported strong agreement with eight statements amongst the 12 included in MEIM. Disagreement with MEIM statements was reported by nearly $20 \%$ or less of the respondents. Participants less likely disagreed with MEIM items that used to identify $A B C$ as compared to the EIS. Mean TEI score was $3.40(95 \% \mathrm{Cl} 3.12,3.48)$, and for subclasses, EIS and $A B C$ was $3.44(95 \% \mathrm{Cl} 3.34,3.53)$ and $3.54(95 \% \mathrm{Cl} 3.45,3.63)$, respectively. The TEI scores were higher if the participants reported using native language at home, attendance at a religious/cultural Sunday school, participation in dance and/or ethnic music classes, regular/frequent visitation of the parent's country of origin, and of those whose relatives regularly/frequently visited their families in the U.S. (Table II). Father's religious and parental membership/leadership in the ethnic/religious organizations was also found to be associated with a higher TEI score as compared to the participants' counterparts (Table II). Generalized Linear Models (GLM) was constructed to identify significance of demographic and family characteristics in prediction of ethnic identity scores (Table III). The VIF scores for predictor variables were not greater than 2.3. Therefore, all selected variables were included into the GLM models without risk for multicollinearity effect. Regression coefficient $(\beta)$ with 95\% Cl presented in Table III showed significant and direct association of participation in dance and or/ethnic music classes and use of native language at home with TEI and subclasses of ethnic identity. Furthermore, $A B C$ stage was found to be positively associated with father's religious and relatives' regularly/frequently visiting the families in the U.S.

Table I. Responses to the MEIM subscales (EIS and ABC)

\begin{tabular}{|c|c|c|c|c|}
\hline Ethnic Identity Search (EIS) & \begin{tabular}{|c|}
$\begin{array}{c}\text { Strongly } \\
\text { agree }\end{array}$ \\
\end{tabular} & Agree & Disagree & $\begin{array}{l}\text { Strongly } \\
\text { disagree }\end{array}$ \\
\hline $\begin{array}{l}\text { I have spent time trying to find out more about my ethnic group history, } \\
\text { traditions and customs }\end{array}$ & $41.1 \%$ & $41.1 \%$ & $12.3 \%$ & $5.5 \%$ \\
\hline $\begin{array}{l}\text { I am active in organizations or social groups that include mostly members } \\
\text { of my own ethnic group }\end{array}$ & $49.1 \%$ & $36.8 \%$ & $11.7 \%$ & $2.5 \%$ \\
\hline $\begin{array}{c}\text { I think a lot about how my life will be affected by my ethnic group } \\
\text { membership }\end{array}$ & $40.5 \%$ & $36.8 \%$ & $19.6 \%$ & $3.1 \%$ \\
\hline I have often talked to other people about my ethnic group & $37.4 \%$ & $40.5 \%$ & $20.2 \%$ & $1.8 \%$ \\
\hline $\begin{array}{l}\text { I participate in cultural practices of my own group, special food, music, } \\
\text { customs or ethnic festivals }\end{array}$ & $63.2 \%$ & $31.3 \%$ & $4.3 \%$ & $1.2 \%$ \\
\hline \multicolumn{5}{|c|}{ Affirmation, Belonging and Commitment (ABC) } \\
\hline I have a clear sense of my ethnic background and what it means for me & $44.8 \%$ & $44.2 \%$ & $9.8 \%$ & $1.2 \%$ \\
\hline I am happy that I am a member of the group I belong to & $66.9 \%$ & $30.1 \%$ & $1.8 \%$ & $1.2 \%$ \\
\hline I have a strong sense of belonging to my own ethnic group & $55.2 \%$ & $35 \%$ & $6.7 \%$ & $3.1 \%$ \\
\hline I understand pretty well what my ethnic group membership means to me & $49.7 \%$ & $41.1 \%$ & $7.4 \%$ & $1.8 \%$ \\
\hline I have a lot of pride in my ethnic group & $60.1 \%$ & $33.1 \%$ & $3.7 \%$ & $3.1 \%$ \\
\hline I feel a strong attachment towards my own ethnic group & $58.9 \%$ & $33.1 \%$ & $6.7 \%$ & $1.2 \%$ \\
\hline I feel good about my cultural or ethnic background & $63.2 \%$ & $35 \%$ & $1.2 \%$ & $0.6 \%$ \\
\hline
\end{tabular}


Table II.Total Ethnic Identity (TEI) score of young with respect to their demographic and family characteristics

\begin{tabular}{|c|c|c|c|}
\hline \multirow{2}{*}{ Responses to the following items } & \multicolumn{2}{|c|}{ Total Ethnic Identity Score } & \multirow{2}{*}{ P-value } \\
\hline & n (\%) & Mean, $95 \% \mathrm{Cl}$ & \\
\hline \multicolumn{4}{|l|}{ I was born in the United States } \\
\hline Yes & $114(73.5)$ & $2.41(3.32,3.49)$ & \multirow{2}{*}{0.70} \\
\hline No & $41(26.5)$ & $3.37(3.18,3.56)$ & \\
\hline \multicolumn{4}{|l|}{ For my high school education, I attended a } \\
\hline Public school & $144(92.9)$ & $3.39(3.31,3.48)$ & \multirow{2}{*}{0.81} \\
\hline Private school & $11(7.1)$ & $3.43(3.10,3.77)$ & \\
\hline \multicolumn{4}{|l|}{ In my teenage years, I grew up in a } \\
\hline Cosmopolitan & $21(13.6)$ & $3.30(2.94,3.65)$ & \multirow{2}{*}{0.27} \\
\hline Suburb & $134(86.4)$ & $2.41(3.33,3.49)$ & \\
\hline \multicolumn{4}{|c|}{ In what language do your parents speak to you } \\
\hline English & $52(33.5)$ & $3.21(3.03,3.39)$ & \multirow{2}{*}{$<0.01$} \\
\hline Native language & $103(66.5)$ & $3.49(3.41,3.57)$ & \\
\hline \multicolumn{4}{|l|}{ My parents if alive are still } \\
\hline Married & $149(97.4)$ & $3.39(3.30,3.47)$ & \multirow{3}{*}{0.39} \\
\hline Divorced & $4(2.6)$ & $3.63(3.13,4.10)$ & \\
\hline Separated & 0 & & \\
\hline \multicolumn{4}{|l|}{ My mother is religious } \\
\hline Yes & $150(96.7)$ & $3.40(3.33,3.48)$ & \multirow{2}{*}{0.27} \\
\hline No & $5(3.3)$ & $3.15(180,4.41)$ & \\
\hline \multicolumn{4}{|l|}{ My father is religious } \\
\hline Yes & $124(80.0)$ & $3.45(3.37,3.53)$ & \multirow{2}{*}{$<0.01$} \\
\hline No & $31(20.0)$ & $3.18(2.94,3.43)$ & \\
\hline \multicolumn{4}{|c|}{ Do your parents subscribe to ethnic TV channels? } \\
\hline Yes & $115(74.2)$ & $3.42(3.33,3.51)$ & \multirow{2}{*}{0.37} \\
\hline No & $40(25.8)$ & $3.33(3.13,3.53)$ & \\
\hline \multicolumn{4}{|c|}{ Is your father a member/leader of an ethnic/religious organization } \\
\hline Yes & $57(36.8)$ & $3.57(3.47,3.68)$ & \multirow{2}{*}{$<0.01$} \\
\hline No & $98(63.2)$ & $3.29(3.18,3.40)$ & \\
\hline \multicolumn{4}{|c|}{ Is your mother a member/leader of an ethnic/religious organization } \\
\hline Yes & $60(38.7)$ & $3.57(3.47,3.68)$ & \multirow{2}{*}{$<0.01$} \\
\hline No & $95(61.3)$ & $3.28(3.17,3.40)$ & \\
\hline \multicolumn{4}{|c|}{ "I attend/attended religious/cultural Sunday school growing up" } \\
\hline Agree/ highly agree & $84(54.2)$ & $3.52(3.43,3.61)$ & \multirow{2}{*}{$<0.01$} \\
\hline Disagree/ highly disagree & $71(45.8)$ & $3.25(3.11,3.38)$ & \\
\hline \multicolumn{4}{|c|}{ I take/took dance and or/ethnic music classes } \\
\hline Yes & $86(57.3)$ & $3.51(3.42,3.61)$ & \multirow{2}{*}{$<0.01$} \\
\hline No & $70(46.7)$ & $3.25(3.12,3.54)$ & \\
\hline If I take or tool dance and or/ethnic music classes, I & & & \\
\hline
\end{tabular}




\begin{tabular}{|c|c|c|c|}
\hline Own choice & $93(70.5)$ & $3.47(3.37,3.56)$ & \multirow{2}{*}{0.11} \\
\hline Parental persuasion & $39(29.5)$ & $3.31(3.11,3.50)$ & \\
\hline \multicolumn{4}{|c|}{ I visit my parent's county of origin } \\
\hline Regularly/ frequently & $84(64.5)$ & $3.48(3.37,3.58)$ & \multirow{2}{*}{$<0.05$} \\
\hline Infrequently/never & $70(45.5)$ & $3.31(3.18,3.44)$ & \\
\hline \multicolumn{4}{|c|}{ My grandparents/relatives visit us in the U.S. } \\
\hline Regularly/ frequently & 87 (56.9) & $3.48(3.39,3.56)$ & \multirow{2}{*}{$<0.03$} \\
\hline Infrequently/never & $66(43.1)$ & $3.29(3.14,3.45)$ & \\
\hline
\end{tabular}

Table III.Results of General Linear Models (GLM) presented as regression coefficient $\beta$ and $95 \% \mathrm{Cl}$

\begin{tabular}{|c|c|c|c|}
\hline Respondent "Yes" coded as $1 \&$ “No" coded as 0 & TEl score & EIS & ABC \\
\hline Parents speak native language at home & $\begin{array}{c}0.19 \\
(0.03,0.34)^{*}\end{array}$ & $\begin{array}{c}0.19 \\
(0.04,0.34)^{*}\end{array}$ & $\begin{array}{c}0.16 \\
(0.01,0.31)^{*}\end{array}$ \\
\hline Religious father & $\begin{array}{c}0.16 \\
(-0.00,0.31)\end{array}$ & $\begin{array}{c}0.09 \\
(-0.07,0.25)\end{array}$ & $\begin{array}{c}0.19 \\
(0.03,0.35)^{*}\end{array}$ \\
\hline Father a member/ leader of an ethnic/ religious organization & $\begin{array}{c}0.02 \\
(-0.0 .21,0.24)\end{array}$ & $\begin{array}{c}0.14 \\
(-0.0 .9,0.37)\end{array}$ & $\begin{array}{c}0.06 \\
(-0.16,0.29)\end{array}$ \\
\hline $\begin{array}{l}\text { Mother a member/ leader of an ethnic/ religious } \\
\text { organization }\end{array}$ & $\begin{array}{c}0.14 \\
(-0.07,0.35)\end{array}$ & $\begin{array}{c}-0.04 \\
(-0.17,0.25)\end{array}$ & $\begin{array}{c}0.18 \\
(-0.03,0.39)\end{array}$ \\
\hline Attend/ attended religious/ cultural Sunday school & $\begin{array}{c}0.12 \\
(-0.05,0.28) \\
\end{array}$ & $\begin{array}{c}0.10 \\
(-0.07,0.26) \\
\end{array}$ & $\begin{array}{c}0.07 \\
(-0.1,0.23) \\
\end{array}$ \\
\hline Take/ took dance and or/ ethnic music classes & $\begin{array}{c}0.19 \\
(0.032,0.34)^{*}\end{array}$ & $\begin{array}{c}0.25 \\
(0.09,0.40)^{*}\end{array}$ & $\begin{array}{c}0.17 \\
(0.02,0.32)^{*}\end{array}$ \\
\hline Regularly/ frequently visited parental country & $\begin{array}{c}0.13 \\
(-0.023,0.28)\end{array}$ & $\begin{array}{c}0.10 \\
(-0.05,0.25)\end{array}$ & $\begin{array}{c}0.12 \\
(-0.020 .28)\end{array}$ \\
\hline Regularly/ frequently relatives visited the U.S. & $\begin{array}{c}0.10 \\
(-0.053,0.26)\end{array}$ & $\begin{array}{c}0.07 \\
(-0.08,0.23)\end{array}$ & $\begin{array}{c}0.16 \\
(0.01,0.31)^{*}\end{array}$ \\
\hline
\end{tabular}
*P $<0.05-0.01$

\section{Discussion}

This report presents data on an association of ethnic identity formation with demographic and family characteristics of predominantly Asian Indian college students born in the U.S. or being a U.S. citizen for more than 10 years. We found significant and direct association of scores characterized by exploration and commitment stages of ethnic identity formation with report by youth of the use of native language at home and previous/current attendance of ethnic dance/ music classes. Father's religious and regular/frequent visitation of relatives also increased the score characterized by the commitment stage of ethnic identity. Studies reported relevance of native language and/or cultural activities, including music and dancing in formation and stabilization of ethnic identity of other ethnic groups. ${ }^{25,28-30}$ perhaps because cultural music has been defined as an opportunity for not only expression of individual but also group identity. ${ }^{31}$ Belonging to other members of the ethnic group reflects ethnical/cultural self-identification ${ }^{5,12}$ which has been found to be positively associated with formation of ethnic identity in American-born Asian Indian adolescents..$^{32}$ Iwamoto et al..$^{33}$ defined formation of ethnic identity in second generation of Asian Indian Americans as an ongoing and lifelong multidimensional process influenced by parental religious practices and discussion of cultural knowledge. Moreover, the authors stressed the importance of Asian Indian youth facing racial/ethnic discrimination and interaction with the same ethnic groups in formation of ethnic identity. Survey of the Americanborn Asian Indian adolescents and their immigrant parents showed positive association between self-identification and development of ethnic identity as well as higher self-esteem, less anxiety, and less family conflict when there was no acculturation gap between adolescents and their parents. ${ }^{34}$ Adaptation of the dominant culture among studies youth was associated with development of their ethnic identity although the ethnic identity and acculturation are related but separate concepts. ${ }^{5,35}$ Significance of ethnic identity in self-identification, psychological functioning, and wellbeing of adolescents and youth ${ }^{9 ; 10,13,14}$ indicates the need for 
better understanding of factors that influence the formation of ethnic identity among American youth of Asian Indian descent as well as the interactive effect of demographic/ family characteristics with youth perception regarding racial/ethnic discrimination.

We would like to acknowledge the study limitations. First, there is a risk for a non-response bias that could be associated with a difference in the personal sense of ethnic identity. Second, selection bias could be considered because not everyone responded to the distributed survey. However, the risk for selection and non-response biases could be reduced because a sample frame of cultural community organizations has been used to target Asian Indian youth. Moreover, inclusion of introductory page, utilization of different methods (via paper and online) for distribution of the anonymous survey, and simplification of the questionnaire by designing close-ended questions to increase response rate could reduce the selection and non-response biases. Third, not collection of the gender, economic status, linguistic and religious multiplicity of participants could be a subject to the recall bias, although others showed no association of ethnic identity scores with gender and social-economic status of adolescents and youth. ${ }^{24}$

\section{Conclusion}

Parental religion and interaction with non-US relatives as well as participation in cultural and ethnic events are the main factors that impact development of exploration and commitment sages in formation of ethnic identify among American youth of Asian Indian descent. Results from our study can be used in psychological counseling as well as in further research to determine the role of formation of ethnic identify stages of Asian Indian origin college students looking for help in mental health.

\section{Acknowledgement}

We would like to acknowledge the late Dr. Vidya Bhushan Gupta, a pediatrician par excellence who designed the survey and provided the insight to study this population subgroup which is increasing in numbers exponentially in the USA. Unfortunately, Dr. Gupta met an early demise and was not able to see the outcome of the study. This paper has been written and submitted as an ode to the profession and his leadership. The authors would also like to thank the Shri Krishna Nidhi (SKN) Foundation for providing the community platform to reach out to the South Asian population. Finally, we would like to thank all of the youth who participated in the study to bring the results presented here.

\section{Conflicts of Interest: None}

\section{References}

1. Berk LE. Infants, children, and adolescents. $7^{\text {th }}$ ed.
Boston, MA: Allyn \& Bacon; 2012.

2. Erikson EH. Identity, youth and crisis. New York: W.W. Norton Company; 1968.

3. Ramirez SS. Developing ethnic identity through Chicano/Latino studies: A case study of high school students in central valley, California [Internet]. Vol. 70, Dissertation Abstracts International Section A: Humanities and Social Sciences. ProQuest Information \& Learning; 2009 [cited 2020 May 23]. p. 62. Available from: https://search.ebscohost.com/login.aspx?dire ct=true \&AuthType $=$ sso \&db=psyh\&AN=2009-99130455\&site=ehost-live.

4. Umaña TAJ, Quintana SM, Lee RM, Cross WE, Rivas DD, Schwartz SJ et al. Ethnic and racial identity during adolescence and into young adulthood: An integrated conceptualization. Child Development. 2014; 85(1): 21 39. Available from: https://search.ebscohost.com/login. aspx?direct=true \&AuthType $=$ sso $\& d b=$ psyh $\& A N=2014$ 04324-003\&site=ehost-live.

5. Phinney JS. Ethnic identity in adolescents and adults: Review of research. Psychological Bulletin. 1990; 108(3): 499-514. Available from: https://search.ebscohost. com/login.aspx?direct=true \&AuthType $=$ sso \&db=psy h\&AN=1991-07036-001\&site=ehost-live.

6. Phinney JS. Ethnic and racial identity: Ethnic identity. In: Kazdin AE, editor. Encyclopedia of Psychology, Vol 3 [Internet]. Washington, DC; New York, NY: American Psychological Association; 2000 [cited 2020 May 23]. p. 254-9. Available from: https://search.ebscohost. com/login.aspx?direct=true\&AuthType $=$ sso \& db=psy h\&AN=2004-12701-122\&site=ehost-live

7. Wakefield WD, Hudley C. Ethnic and Racial Identity and Adolescent Well-Being. Theory Into Practice 2007; 46(2): 147-154.

8. Roberts RE, Phinney JS, Masse LC, Chen YR, Roberts CR, Romero A. The structure of ethnic identity of young adolescents from diverse ethnocultural groups. The Journal of Early Adolescence 1999; 19(3): 301-22. Available from: https://search.ebscohost.com/login. aspx?direct=true \&AuthType $=$ sso $\& d b=$ psyh \&AN=199903518-001\&site=ehost-live.

9. Fisher S, Reynolds JL, Hsu W-W, Barnes J, Tyler K. Examining multiracial youth in context: Ethnic identity development and mental health outcomes. Journal of Youth and Adolescence 2014; 43(10): 1688-1699. Available from: https://search.ebscohost.com/login. aspx?direct=true \&AuthType $=s s o \& d b=$ syh $\& A N=2014$ 33042-001\&site=ehost-live.

10. Smokowski PR, Evans CBR, Cotter KL, Webber KC. Ethnic identity and mental health in American Indian youth: Examining mediation pathways through self-esteem, and future optimism. Journal of Youth and Adolescence 2014; 43(3): 343-355. Available from: https://search. 
ebscohost.com/login.aspx?direct=true\&AuthType=s so\&db=psyh\&AN=2013-29002-001\&site=ehost-live

11. French SE, Seidman E, Allen L, Aber JL. The development of ethnic identity during adolescence. Developmental Psychology 2006;42(1): 1-10. Available from: https:// search.ebscohost.com/login.aspx?direct=true\&AuthT ype $=$ sso \&db=psyh\&AN=2006-00646-001\&site=ehostlive.

12. Phinney JS. Ethic identity and acculturation. In: Chun KM, Balls Organista P, Marín G, editors. Acculturation: Advances in theory, measurement, and applied research [Internet]. Washington, DC: American Psychological Association; 2003 [cited 2020 May 23]. p. 63-81. Available from: https://search.ebscohost.com/login. aspx?direct=true \&AuthType $=$ sso $\& d b=$ psyh $\& A N=2002-$ 18425-006\&site=ehost-live.

13. Markstrom CA, Whitesell N, Galliher RV. Ethnic identity and mental health among American Indian and Alaska Native adolescents. In: Sarche MC, Spicer P, Farrell P, Fitzgerald $\mathrm{HE}$, editors. American Indian and Alaska Native children and mental health: Development, context, prevention, and treatment [Internet]. Santa Barbara, CA: Praeger/ABC-CLIO; 2011 [cited 2020 May 23]. p. 101-31. (Child psychology and mental health). Available from: https://search.ebscohost.com/login.as px?direct $=$ true $\&$ AuthType $=s s o \& d b=$ syh $\& A N=2011-$ 23063-006\&site=ehost-live

14. Martinez RO, Dukes RL. The effects of ethnic identity, ethnicity, and gender on adolescent well-being. Journal of Youth and Adolescence 1997; 26(5): 503-516. Available from: https://search.ebscohost.com/login. aspx?direct=true \&AuthType=sso\&db=psyh\&AN=199742481-001\&site=ehost-live.

15. Rivas DD, Seaton EK, Markstrom C, Quintana S, Syed M, Lee RM et al. Ethnic and racial identity in adolescence: Implications for psychosocial, academic, and health outcomes. Child Development 2014; 85(1): 40-57. Available from: https://search.ebscohost.com/login. aspx?direct=true \&AuthType $=$ sso\& $d b=p s y h \& A N=2014-$ 04324-004\&site=ehost-live.

16. Williams JL, Tolan PH, Durkee MI, Francois AG, Anderson RE. Integrating racial and ethnic identity research into developmental understanding of adolescents. Child Development Perspectives 2012; 6(3): 304-311. Available from: https://search.ebscohost.com/login.as px?direct=true \&AuthType $=$ sso $\& d b=$ syh \&AN=201222562-014\&site=ehost-live.

17. Smith TB, Silva L. Ethnic identity and personal wellbeing of people of color: A meta-analysis. Journal of Counseling Psychology 2011; 58(1): 42-60. Available from: https://search.ebscohost.com/login.aspx?dire $\mathrm{ct}=$ true \&AuthType $=$ sso $\& \mathrm{db}=$ psyh $\& A N=2010-26147-$ 001\&site=ehost-live.
18. Waxler-Morrison N, Anderson J, Richardson E. Crosscultural caring: A handbook for health professionals in western Canada. In: The South Asians. Vancouver, BC: University of British Columbia Press 1990; 141-180.

19. Ibrahim F, Ohnishi H, Sandhu DS. Asian American identity development: A culture specific model for South Asian Americans. Journal of Multicultural Counseling and Development 1997; 25(1):34-50. Available from: https://search.ebscohost.com/login. aspx?direct=true \&AuthType=sso\&db=psyh\&AN=199707241-003\&site=ehost-live.

20. Dion KK, Dion KL. Gender and cultural adaptation in immigrant families. Journal of Social Issues 2001; 57(3): 511-521. Available from: https://search.ebscohost. com/login.aspx?direct=true \&AuthType $=$ sso $\& d b=$ psy h\&AN=2001-10225-007\& site=ehost-live.

21. Dosanjh JS, Ghuman PAS. Child-rearing practices of two generations of Punjabis: development of personality and independence. Children \& Society 1998; 12(1): 25-37.

22. Shariff A. Ethnic identity and parenting stress in South Asian families: Implications for culturally sensitive counselling. Canadian Journal of Counselling 2009; 43(1): 35-46. Available from: https://search.ebscohost. com/login.aspx?direct=true \&AuthType $=$ sso \&db=psyh \&AN=2009-02320-003\&site=ehost-live.

23. Phinney JS. Stages of ethnic identity development in minority group adolescents. The Journal of Early Adolescence 1989; 9(1-2): 34-49. Available from: https://search.ebscohost.com/login.aspx?direct= true \&AuthType $=$ sso \&db=psyh \&AN $=1989-39658$ 001\&site=ehost-live.

24. Phinney JS. The multigroup ethnic identity measure: A new scale for use with diverse groups. Journal of Adolescent Research 1992; 7(2): 156-176. Available from: https://search.ebscohost.com/login.aspx?dire $\mathrm{ct}=$ true \&AuthType $=\mathrm{sso} \& \mathrm{db}=$ psyh\&AN=1992-33567001\&site=ehost-live.

25. Trimillos RD. Music and Ethnic Identity: Strategies among Overseas Filipino Youth. Yearbook for Traditional Music. Cambridge University Press 1986; 18: 9-20.

26. Iwamoto DK, Liu WM. The impact of racial identity, ethnic identity, Asian values and race-related stress on Asian Americans and Asian international college students' psychological well-being. Journal of Counseling Psychology 2010; 57(1): 79-91. Available from: https://search.ebscohost.com/login.aspx?dire $\mathrm{ct}=$ true $\&$ AuthType $=$ sso $\& \mathrm{db}=$ psyh\&AN $=2010-00483$ 011\&site=ehost-live

27. Cohen JG, Cohen PS, West SG, Aiken LS. Applied Multiple Regression/Correlation Analysis for the Behavioral Science. Mahwah: Laurence Erlbaum; 2003.

28. Inman AG, Howard EE, Beaumont RL, Walker JA. 
Cultural transmission: Influence of contextual factors in asian indian immigrant parents' experiences. Journal of Counseling Psychology 2007;54(1): 93-100. Available from: https://search.ebscohost.com/login.aspx?dire $\mathrm{ct}=$ true \&AuthType $=$ sso $\& \mathrm{db}=$ psyh \&AN=2006-23057009\&site $=$ ehost-live.

29. Issari P. Greek American ethnic identity, cultural experience and the 'embodied language' of dance: Implications for counseling. International Journal for the Advancement of Counselling 2011; 33(4): 252-265. Available from: https://search.ebscohost.com/login. aspx?direct=true \&AuthType $=$ sso $\& d b=p s y h \& A N=2011$ 29293-003\&site=ehost-live.

30. Schweigman K, Soto C, Wright S, Unger J. The relevance of cultural activities in ethnic identity among California Native American youth. Journal of Psychoactive Drugs 2011; 43(4): 343-348. Available from: https://search. ebscohost.com/login.aspx?direct=true\&AuthType=s so\&db=psyh\&AN=2012-02266-013\&site=ehost-live.

31. Lidskog $R$. The role of music in ethnic identity formation in diaspora: a research review. International Social Science Journal 2017; 66(219-220): 23-38.

32. Yip T. Ethnic identity in everyday life: The influence of identity development status. Child Development 2014; 85(1): 205-219. Available from: https://search. ebscohost.com/login.aspx?direct=true\&AuthType=s so\&db=psyh\&AN=2014-04324-014\&site=ehost-live.

33. Iwamoto DK, Negi NJ, Partiali RN, Creswell JW. The racial and ethnic identity formation process of second-generation Asian Indian Americans: A phenomenological study. Journal of Multicultural Counseling and Development 2013; 41(4): 224-39. Available from: https://search.ebscohost.com/login. aspx?direct=true \&AuthType $=$ sso \&db=psyh \&AN=201335769-003\&site=ehost-live

34. Farver JAM, Narang SK, Bhadha BR. East meets West: Ethnic identity, acculturation, and conflict in Asian Indian families. Journal of Family Psychology 2002; 16(3): 338-350. Available from: https://search. ebscohost.com/login.aspx?direct=true\&AuthType=s so\&db=psyh\&AN=2002-15689-008\&site=ehost-live.

35. Berry JW, Trimble JE, Olmedo EL. Assessment of acculturation. In: Lonner WJ, Berry JW, editors. Field methods in cross-cultural research [Internet]. Thousand Oaks, CA: Sage Publications, Inc; 1986 [cited 2020 May 23]. 291-324. (Cross-cultural research and methodology series, Vol. 8). Available from: https://search.ebscohost. com/login.aspx?direct=true \&AuthType=sso \&db=psyh $\& A N=1987-97046-010 \&$ site=ehost-live. 